\title{
PERBANDINGAN KAPASITAS VITAL PAKSA PARU PADA MAHASISWA PEROKOK DAN BUKAN PEROKOK DI FAKULTAS KEDOKTERAN UNIVERSITAS SAM RATULANGI MANADO
}

\author{
${ }^{1}$ Rokky V. Barakati \\ ${ }^{2}$ Fransiska Lintong \\ ${ }^{2}$ Maya E.W. Moningka \\ ${ }^{1}$ Kandidat Skripsi Bagian Fisika Kedokteran Universitas Sam Ratulangi Manado \\ ${ }^{2}$ Bagian Fisika Kedokteran Universitas Sam Ratulangi Manado \\ Email: nandobarakati@yahoo.com
}

\begin{abstract}
Indonesia is one of the countries with the highest smoking prevalence in the world. Tobacco is a major component of smoking may cause the death of half of its consumers. Cigarettes contain more than 4000 chemicals are exposed through cigarette smoke. Lung function as an exchange of oxygen and carbon dioxide into place exchange of substances contained in cigarettes, which would cause damage to the lungs. This study aimed to know the difference of Forced VitalCapacity (FVC) among students smokers and non-smokers in the Medical Faculty of Sam Ratulangi University. This was a cross sectional analytic survey (cross-sectional). The location was at Prodia Laboratory Manado. There were 40 samples ion this stiudy. The results showed that the value of $p=0.003<\alpha=0.05$, and concluded that there were significant differences between students who smoked and who did not.
\end{abstract}

Keywords: students smokers, students non-smokers, forced vital capacity

\begin{abstract}
Abstrak:Indonesia merupakan salah satu negara dengan angka prevalensi merokok tertinggi di dunia. Tembakau yang merupakan komponen utama rokok dapat menyebabkan kematian setengah dari penggunanya. Rokok mengandung lebih dari 4000 bahan kimia yang dipaparkan melalui asap rokok. Paru-paru yang berfungsi sebagai tempat pertukaran oksigen dengan karbon dioksida menjadi tempat pertukaran zat yang terkandung dalam rokok, yang akan menyebabkan teradinya kerusakan pada paru-paru. Tujuan dari penelitian ini yaitu mengetahui perbedaan Kapasitas Vital Paksa (KVP) pada Mahasiswa perokok dan bukan perokok di Fakultas Kedokteran Universitas Sam Ratulangi. Penelitian ini merupakan penelitian analitik. Desain penelitian yaitu cross sectional atau studi potong lintang, dimana pengukuran hanya dilakukan satu kali pada satu saat pada suatu populasi di wilayah tersebut. Lokasi penelitian dilakukan di Laboratorium Klinik Prodia Manado. Sampel pada penelitian ini berjumlah 40 orang. Hasil penelitian ini menunjukkan bahwa nilai $\mathrm{p}=0.003<\alpha=0,05$, dan dapat disimpulkan bahwa terdapat perbedaan yang bermakna antara Mahasiswa perokok dan bukan perokok.
\end{abstract}

Kata kunci: mahasiswa perokok, mahasiswa bukan perokok, kapasitas vital paksa paru

Indonesia merupakan salah satu negara dengan angka prevalensi merokok tertinggi di dunia. Prevalensi merokok terus meningkat baik pada laki-laki maupun perempuan. Pada tahun 2007, hampir semua provinsi menunjukkan kenaikan prevalensi merokok, kecuali di Provinsi
Bali. Lebih dari setengah laki-laki adalah perokok yaitu sebesar $65,6 \%$ sedangkan perempuan sebesar 5,2\%. Prevalensi lakilaki perokok tertinggi di Sulawesi tenggara yaitu $74,2 \%{ }^{1,2}$ Pada tahun 2013 , perilaku merokok pada penduduk usia 15 tahun keatas cenderung meningkat dari 34,2\% 
Barakati, Lintong, Moningka: Perbandingan kapasitas vital...

pada tahun 2007 menjadi 36,3 \%. Jumlah rerata batang rokok terbanyak yang dihisap adalah Bangka Belitung yaitu 18,3 batang per hari sedangkan sulawesi utara sebanyak 13,2 batang per hari. ${ }^{3}$ Menurut laporan WHO, pada tahun 2009 angka prevalensi laki-laki perokok yang berusia 15 tahun keatas tertinggi di pasifik barat yaitu sekitar $51 \%$ dan perempuan perokok tertinggi di kawasan Eropa yaitu sekitar 22 \%. ${ }^{4}$

Tembakau yang merupakan komponen utama rokok dapat menyebabkan kematian setengah dari penggunanya. Tembakau membunuh hampir enam juta orang setiap tahun. Lebih dari lima juta orang meninggal akibat penggunaan tembakau secara langsung yaitu melalui rokok sedangkan lebih dari 600.000 terjadi pada perokok pasif. Jika tidak ditangani dengan serius, pada tahun 2030 diperkirakan kematian akan meningkat hingga delapan juta kematian. $^{5}$

Rokok mengandung lebih dari 4000 bahan kimia yang dipaparkan melalui asap rokok. Paru-paru yang berfungsi sebagai tempat pertukaran oksigen dengan karbondioksida menjadi tempat pertukaran zat yang terkandung dalam rokok, yang akan menyebabkan teradinya kerusakan pada paru-paru. Lebih dari $90 \%$ kanker paru disebabkan oleh rokok. Selain itu, penyakit paru obstruksi menahun yang merupakan keterbatasan aliran udara yang bersifat progresif juga disebabkan oleh rokok dimana terdapat respon inflamasi paru abnormal terhadap partikel atau gas beracun yang berasal dari rokok. Banyaknya zat kimia yang terkandung dalam rokok menyebabkan kemungkinan teradinya penurunan fungsi paru yang dinilai dengan menggunakan indikator spirometri. Hasil penelitian yang dilakukan oleh Putra AN membuktikan bahwa adanya pengaruh dan hubungan merokok terhadap kapasitas vital paru, namun kapasitas vital paksa belum di teliti ${ }^{6-9}$

Berdasarkan latar belakang diatas, peneliti tertarik untuk melakukan penelitian tentang "Perbandingan Kapasitas Vital Paksa Paru Pada Mahasiswa Perokok dan Bukan Perokok di Fakultas Kedokteran
Universitas Sam Ratulangi Manado”.

\section{METODE PENELITIAN}

Penelitian ini merupakan penelitian observasional analitik dengan menggunakan rancangan cross sectional, dimana pengukuran hanya dilakukan satu kali pada satu saat pada suatu populasi. Dilakukan pada bulan NovemberDesember 2014 di Laboratorium Klinik Prodia Manado. Sampel yang menjadi subjek penelitian adalah Mahasiswa perokok dan bukan perokok FakultasKedokteran Universitas Sam Ratulangi yang berjumlah 40 orangyang terdiri dari 20 Mahasiswa perokok dan 20 Mahasiswa bukan perokok. Metode pengambilan sampel pada penelitian ini adalah purposive samplingyaitu didasarkan pada pertimbangan tertentu yang dibuat oleh peneliti sendiri.

\section{HASIL PENELITIAN}

Tabel 1. Distribusi Responden Berdasarkan Usia

\begin{tabular}{ccc}
\hline Usia & $\mathrm{n}$ & $\%$ \\
\hline 19 tahun & 4 & 10 \\
20 tahun & 9 & 22,5 \\
21 tahun & 16 & 40 \\
22 tahun & 8 & 20 \\
23 tahun & 3 & 7,5 \\
\hline Total & 40 & 100 \\
\hline
\end{tabular}

Tabel 2. Distribusi Responden Berdasarkan Berat Badan

\begin{tabular}{ccc}
\hline Berat Badan & $\mathrm{n}$ & $\%$ \\
\hline$<50 \mathrm{~kg}$ & 5 & 12,5 \\
$50-60 \mathrm{~kg}$ & 13 & 32,5 \\
$>60 \mathrm{~kg}$ & 22 & 55,0 \\
\hline Total & 40 & 100 \\
\hline
\end{tabular}

Tabel 3. Distribusi Responden Berdasarkan Tinggi Badan

\begin{tabular}{ccc}
\hline Tinggi Badan & $\mathrm{N}$ & $\%$ \\
\hline$<160 \mathrm{~cm}$ & 2 & 5 \\
$160-170 \mathrm{~cm}$ & 26 & 65 \\
$>170 \mathrm{~cm}$ & 12 & 30 \\
\hline Total & 40 & 100 \\
\hline
\end{tabular}


Tabel 4. Distribusi Responden Berdasarkan Indeks Massa Tubuh

\begin{tabular}{ccc}
\hline IMT & $\mathrm{n}$ & $\%$ \\
\hline Berat Badan Kurang & 1 & 2,5 \\
Normal & 28 & 70,0 \\
Obesitas & 11 & 27,5 \\
\hline Total & 40 & 100 \\
\hline
\end{tabular}

Tabel 5. Distribusi Responden Berdasarkan Lama Merokok

\begin{tabular}{ccc}
\hline Lama Merokok & $\mathrm{n}$ & $\%$ \\
\hline 2 tahun & 4 & 20 \\
3 tahun & 7 & 35 \\
4 tahun & 5 & 25 \\
5 tahun & 4 & 20 \\
\hline Total & 20 & 100 \\
\hline
\end{tabular}

Tabel 6. Distribusi Responden Berdasarkan Jumlah Rokok Per Hari

\begin{tabular}{ccc}
\hline $\begin{array}{c}\text { Jumlah Batang } \\
\text { Rokok Per Hari }\end{array}$ & $\mathrm{n}$ & $\%$ \\
\hline 6 btg & 4 & 20 \\
8 btg & 4 & 20 \\
$10 \mathrm{btg}$ & 4 & 20 \\
$12 \mathrm{btg}$ & 5 & 25 \\
14 btg & 3 & 15 \\
\hline Total & 20 & 100 \\
\hline
\end{tabular}

Tabel 7. Nilai KVP Pada Mahasiswa Bukan Perokok

\begin{tabular}{ccc}
\hline KVP (\%) Pred & $\mathrm{n}$ & $\%$ \\
\hline 75,30 & 1 & 2,5 \\
82,60 & 2 & 5,0 \\
83,60 & 1 & 2,5 \\
86,30 & 1 & 2,5 \\
89,60 & 1 & 2,5 \\
91,40 & 1 & 2,5 \\
91,90 & 1 & 2,5 \\
92,30 & 1 & 2,5 \\
92,80 & 1 & 2,5 \\
92,90 & 1 & 2,5 \\
96,10 & 1 & 2,5 \\
98,70 & 1 & 2,5 \\
99,30 & 1 & 2,5 \\
100,00 & 1 & 2,5 \\
100,20 & 1 & 2,5 \\
101,70 & 1 & 2,5 \\
103,30 & 1 & 2,5 \\
109,40 & 1 & 2,5 \\
116,00 & 1 & 2,5 \\
\hline Total & 20 & 100,0 \\
\hline
\end{tabular}

Tabel 8. Hasil statistik nilai KVP pada mahasiswa bukan perokok

\begin{tabular}{ccccc}
\hline $\begin{array}{c}\text { KVP (\%) } \\
\text { Pred }\end{array}$ & Mean & $\begin{array}{c}\text { Std. } \\
\text { Deviasi }\end{array}$ & Min & Max \\
\hline $\begin{array}{c}\text { Mahasiwa } \\
\text { Bukan } \\
\text { Perokok }\end{array}$ & 94,3 & 9,7530 & 75,3 & 116 \\
\hline
\end{tabular}

Tabel 9. Nilai KVP Pada Mahasiswa Perokok

\begin{tabular}{ccc}
\hline KVP $(\%)$ Pred & N & $\%$ \\
\hline 69,40 & 1 & 2,5 \\
72,70 & 1 & 2,5 \\
75,20 & 2 & 5,0 \\
79,70 & 1 & 2,5 \\
80,20 & 1 & 2,5 \\
80,40 & 1 & 2,5 \\
80,60 & 1 & 2,5 \\
82,00 & 1 & 2,5 \\
82,40 & 1 & 2,5 \\
83,00 & 1 & 2,5 \\
83,60 & 1 & 2,5 \\
84,50 & 1 & 2,5 \\
88,60 & 1 & 2,5 \\
89,70 & 1 & 2,5 \\
91,90 & 1 & 2,5 \\
93,10 & 1 & 2,5 \\
99,00 & 1 & 2,5 \\
100,50 & 1 & 2,5 \\
101,80 & 1 & 2,5 \\
\hline Total & 20 & 100,0 \\
\hline
\end{tabular}

Tabel 10. Hasil statistik nilai KVP pada mahasiswa perokok

\begin{tabular}{ccccc}
\hline $\begin{array}{c}\text { KVP (\%) } \\
\text { Pred }\end{array}$ & Mean & $\begin{array}{c}\text { Std. } \\
\text { Deviasi }\end{array}$ & Min & Max \\
\hline $\begin{array}{c}\text { Mahasiwa } \\
\text { Perokok }\end{array}$ & 84,7 & 9,0757 & 69,4 & 101,8 \\
\hline
\end{tabular}

Tabel 11. Analisis Statistik Independen t-Test

\begin{tabular}{cc}
\hline Uji Statistik & Hasil \\
\hline Independen t-Test & $\mathrm{p}=, 003$ \\
\hline
\end{tabular}

\section{BAHASAN}

Pada analisa univariat didapatkan responden yang memiliki usia terendah yaitu 23 tahun berjumlah 3 orang dengan persentase $7,5 \%$ dan responden yang memiliki usia tertinggi yaitu 21 tahun berjumlah 16 orang dengan persentase 40 $\%$. Penelitian yang dilakukan oleh 
Mujiwati $\mathrm{H}$ pada pekerja industri meubel kayu didapatkan bahwa semakin bertambahnya usia maka nilai kapasitas vital paksa (KVP) paru semakin menurun. ${ }^{10}$

Pada pengukuran berat badan didapatkan responden dengan berat badan terbanyak adalah $>60 \mathrm{~kg}$ yang berjumlah 22 orang dengan persentase $55 \%$ dan responden yang memiliki berat badan $<50$ $\mathrm{kg}$ berjumlah 5 orang dengan persentase $12,5 \%$. Pada pengukuran tinggi badan didapatkan responden yang memiliki tinggi badan 160-170 cm berjumlah 26 orang dengan persentase $65 \%$ sedangkan responden dengan tinggi badan $<160 \mathrm{~cm}$ berjumlah 2 orang dengan persentase $5 \%$. Berdasarkan berat badan dan tinggi badan, didapatkan nilai indeks massa tubuh. Jumlah responden dengan indeks massa tubuh normal sebanyak 28 orang dengan persentase $70 \%$ sedangkan indeks massa tubuh obesitas berjumlah 11 orang dengan persentase $27,5 \%$ dan yang memiliki indeks massa tubuh berat badan kurang berjumlah 1 orang dengan persentase 2,5 $\%$. Pada penelitian yang dilakukan oleh Pinzon R didapatkan bahwa indeks massa tubuh dapat mempengaruhi kapasitas vital paru. Pada penelitian yang dilakukan oleh Jones RL dan Nzekwu MM juga mendapatkan hasil yang sama yang mengatakan bahwa indeks massa tubuh mempunyai pengaruh yang signifikan terhadap volume paru. ${ }^{11,12}$

Lama merokok pada responden perokok didapatkan terbanyak pada jangka waktu merokok selama 3 tahun dengan jumlah 7 orang dengan persentase $35 \%$ dan yang paling sedikit 2 tahun dan 5 tahun masing-masing sebanyak 4 orang dengan persentase $20 \%$. Jumlah rokok yang dihisap oleh responden perokok terbanyakyaitu menghisap rokok 12 batang per hari dengan jumlah 15 orang dengan persentase $25 \%$ dan yang paling sedikit 3 batang per hari sebanyak 3 orang dengan persentase 15\%. Pada penelitian yang dilakukan oleh Armitasari Y didapatkan bahwa penurunan kapasitas vital paru diakibatkan oleh kebiasaan merokok. ${ }^{13}$
Pada pengukuran nilai Kapasitas Vital Paksa (KVP) Paru pada kelompok bukan perokok dengan menggunakan alat spirometri didapatkan responden yang mempunyai KVP terendah berjumlah satu orang dengan nilai KVP yaitu 75,3 \% pred dan yang paling tinggi nilai KVP nya yaitu $116 \%$ pred. Hasil statistik nilai KVP pada kelompok bukan perokok didapatkan nilai mean 94,3 \% pred dengan standar deviasi (sd) 9,753. Sedangkan pada pengukuran nilai Kapasitas Vital Paksa (KVP) Paru pada kelompok perokok, didapatkan responden yang mempunyai KVP terendah berjumlah satu orang dengan nilai KVP yaitu 69,4 \% pred dan yang paling tinggi nilai KVP nya yaitu 101,8 \% pred. Hasil statistik nilai KVP pada kelompok perokok didapatkan nilai mean 84,675 \% pred dengan standar deviasi (sd) 9,0757.

Berdasarkan hasil analisa dengan menggunakan uji independen t-test didapatkan perbedaan yang bermakna pada KVP kelompok mahasiswa perokok dan bukan perokok dengan nilai $\mathrm{p}=0,003<\alpha=$ 0,05 . Penelitian ini sesuai dengan penelitian yang dilakukan oleh Basuki, dkk, dimana pada penelitiannya didapatkan bahwa terdapat perbedaan yang bermakna terhadap nilai Kapasitas Vital Paksa (KVP) antara laki-laki perokok dan bukan perokok dengan nilai $\mathrm{p}=0,000$. Selain itu, penelitian yang dilakukan oleh Bajentri AL, dkk juga membuktikan bahwa merokok dengan jangka waktu 2-5 tahun dengan rata-rata 10 batang per hari terdapat hasil yang signifikan terhadap penurunan fungsi paru salah satunya adalah kapasitas vital paksa (KVP) paru dan cenderung menyebabkan penyempitan pada saluran udara. $^{14,15}$

\section{SIMPULAN}

1. Terdapat perbedaan yang bermakna $(\mathrm{p}<0,05)$ pada nilai Kapasitas Vital Paksa (KVP) Mahasiswa perokok dengan nilai rata-rata 84,675 \% pred.

2. Terdapat perbedaan yang bermakna $(p<0,05)$ pada nilai Kapasitas Vital Paksa (KVP) Mahasiswa bukan perokok dengan nilai rata-rata $94,3 \%$ pred. 


\section{SARAN}

1. Perlu memaksimalkan sosialisasi bahaya merokok pada semua kalangan termasuk dalam dunia kesehatan.

2. Perlu dilakukan penelitian lebih lanjut dengan teknik pengambilan sampel berbeda dengan teknik yang digunakan pada penelitian ini.

3. Perlu dilakukan peneitian lebih lanjut untuk mengetahui nilai KVP pada Mahasiswa perokok dan bukan perokok dengan beberapa faktor pendukung, seperti faktor berat badan, tinggi badan, berolahraga, dan kelompok usia (tidak berdiri sendiri) sebagai bahan perbandingan.

\section{DAFTAR PUSTAKA}

1. Konsumsi rokok dan prevalensi merokok. [diakses pada 25 oktober 2014].Available From: http://ino.searo.who.int/

2. Kusumawardani N. Masalah Rokok di Indonesia. Tobacco Control Support Center-IAKMI. [di akses pada 25 oktober]. Available From: tcscindonesia.org\%2Fwp-

content\%2Fuploads\%2F2012\%2F10

\%2FMasalah-Rokok-di-Indonesia.pdf

3. Badan Penelitian dan Pengembangan Kesehatan. Riset kesehatan dasar (Riseksdas) $2013 . \quad$ Jakarta: Kementerian Kesehatan Republik Indonesia; 2013. p.135.

4. World health organization (WHO). Prevalance of Tobacco Use. [diakses pada 25 oktober 2014]. Available From:

http://www.who.int/gho/tobacco/use/ en/

5. World Health Organization (WHO). Tobacco. Mei 2014 [diakses pada 25 oktober]. Tersedia dari : http://www.who.int/mediacentre/facts heets/fs339/en/
6. Macnair P. Smoking-Health Risk. [diakses pada 26 oktober 2014]. Tersedia dari: http://www.netdoctor.co.uk/health_ad vice/facts/smokehealth.htm

7. What are the helath risks of smoking?.November 2011 [diakses pada 26 oktober 2014]. Tersedia dari: http://www.nhs.uk/chq/Pages/2344.as px?CategoryID $=53$

8. Fitriani F, Yunus F, Wiyono WH, Antariksa B. Penyakit Paru Obstruksi Kronik Sebagai Penyakit Sistemik. J Respir Indo 2007;27:4855.

9. Putra AN. Pengaruh dan hubungan merokok terhadap kapasitas vital paru pada pria dewasa. Bandung: Universitas Kristen Maranatha; 2006.

10. Mujiwati H. Faktor-faktor yang berhubungan dengan gangguan fungsi paru pekerja industri meubel kayu cv. Wajawana di desa bawu jepara. Jepara;1999.

11. Pinzon R. Hubungan indeks massa tubuh dengan kapasitas vital paru-paru pada usia muda. Yogyakarta; FK Universitas Gajah Mada;1999(26);1.

12. Jones RL, Nzekwu MM. The effects of body mass index on lung volumes. Chest. Sep 2006;130(3):827-33.

13. Armitasari $\mathbf{Y}$. Hubungan kebiasaan merokok dan kebiasaan olahraga dengan kapasitas vital paru (studi pada lanjut usia di desa bener kecamatan ngrampal kabupaten sragen. Semarang: FK Universitas Diponegoro.2011

14. Basuki SR, Wahyu S, Dewi ND, Dona. Pengaruh merokok terhadap faal paru. Surakarta:Universitas Muhammadiyah Surakarta;2012.

15. Bajentri AL, Veeranna N, Dixit PD, Kulkarni SB. Effect of 2-5 years of tobacco smoking on ventilatory function tests.J Indian Med Assoc. Feb 2003;101(2):96-7, 108. 